УДК 656.7.072:656.7:061.5(045)

\title{
ОСОБЛИВОСТІ ДІЯЛЬНОСТІ ХЕНДЛІНГОВИХ КОМПАНІЙ НА РИНКУ АВІАПЕРЕВЕЗЕНЬ
}

\author{
Крапко О.М., к.е.н., асистент \\ Назаренко О.В., студентка (НАУ)
}

\begin{abstract}
Розглянуто дослідження взаємодії хендлінгової компанії та авіакомпаній, щьо дозволяють здійснити діагностику діяльності авіакомпанії в даному аеропорту $i$, таким чином, в подальшому побудувати співпрацю аеропорту з даною авіакомпанією для задоволення потреб споживачів та досягнення найбільшого ефекту функціонування аеропорту. Наголошено на тому, щчо процеси взаємодії хендлінгових структур аеропорту $з$ авіакомпаніями відносяться до стратегічних процесів аеропорту. Створена схема взаємодії хендлінгової компанії з авіакомпанією виявляє проблемні авіакомпанії $і$ є однією із складових для розробки стратегї розвитку аеропорту.

Основне завдання хендлінгової компанії - безперебійне забезпечення авіапаливом, надання повного комплексу послуг суб'єктам авіаційної діяльності при суворому дотриманні вимог $і$ нормативів авіаційної безпеки. В компанії створена власна матеріально-технічна база, сформований трудовий колектив з фахівців, які мають великий досвід роботи в циивільній авіації.
\end{abstract}

Ключові слова: хендлінгова компанія, авіакомпанія, аеропорт, діяльність, компанія.

\section{ОСОБЕННОСТИ ДЕЯТЕЛЬНОСТИ ХЕНДЛИНГОВЫХ КОМПАНИЙ НА РЫНКЕ АВИАПЕРЕВОЗОК}

\author{
Крапко А.Н., к.э.н., ассистент \\ Назаренко А.В., студентка (НАУ)
}

Рассмотрены исследования взаимодействия хэндлинговой компании и авиакомпаний, позволяющце осуществить диагностику деятельности авиакомпании в данном аэропорту и, таким образом, в дальнейшем построить сотрудничество аэропорта с данной авиакомпанией для удовлетворения потребностей потребителей и достижения наибольшего эффекта функиионирования аэропорта. Отмечено, что процессы взаимодействия хендлинговых структур аэропорта с авиакомпаниями относятся к стратегическим прочессов аэропорта. Созданная схема взаимодействия хэндлинговой компании с авиакомпанией обнаруживает проблемные авиакомпании и является одной из составляющих для разработки стратегии развития аэропорта.

Основная задача хэндлингвой компании - бесперебойное обеспечение авиатопливом, предоставление полного комплекса услуг субъектам авиационной деятельности при строгом соблюдении требований и нормативов авиационной безопасности. В компании создана собственная материально-техническая база, сформирован трудовой коллектив из специалистов, которые имеют большой опыт работы в гражданской авиации.

Ключевые слова: хендлинговя компания, авиакомпания, аэропорт, деятельность, компания.

\section{FEATURES OF THE HANDLING COMPANY COMPANIES IN THE AIR}

\author{
Krapka A.N., Ph.D., assistant \\ $N$ azarenko A.V., student (NAU)
}

Considered Interaction handling company and airlines, enabling a diagnosis of airlines in this airport, thus further build cooperation with this airline airport to meet consumer needs and achieve the best effect functioning airport. Emphasized that the processes of interaction handling structures airport with airlines relating to strategic processes airport. Established interaction diagram handling company with the airline finds problematic airlines is one of the components of the development strategy for the airport.

The main objective of Handling Company - uninterrupted supply of aviation fuel, providing a full range of services to business aviation activities in strict compliance with the requirements and standards of aviation security. The company created its own material base formed by the labor collective of specialists with extensive experience in civil aviation.

Keywords: handling company, airline, airport, activity, company.

\section{Постановка проблеми}

(C) Крапко O.M.,

Назаренко О.В. 
3 постановкою гострої проблеми підвищення конкурентоспроможності сучасних аеропортів на світовому ринку авіаперевезень та недосконалості розробки даної проблематики в науковій літературі постає проблема підвищення ефективності, якості надання послуг та передачі прав на надання послуг профільним компаніям. Управління співпрацею аеропортів 3 даними компаніями $є$ досить новим об’єктом наукових досліджень, що і визначило вибір завдання та теми досліджень.

Враховуючи високий рівень надаваних послуг, за рішенням сертифікаційної комісії Державної авіаційної служби Міністерства інфраструктури України, хедлінгові компанії отримали право надання послуг 3 авіапаливозабезпечення авіаційних перевезень та робіт (прийом, зберігання, підготовка до видачі та видача на заправку в паливозаправочні кошти, заправка повітряних суден авіапаливом), обслуговування пасажирів і багажу (реєстрація та оформлення пасажирів, їх посадка (висадка) в ПС; обробка багажу, його навантаження (вивантаження) на борт (з борту) ПС; оформлення відповідної перевізної документації) наземному адміністрування.

Аналіз останніх досліджень і публікацій

Питання аналізу процесу взаємодії аеропортів та авіакомпаній України розглядалися Костроминою Е.В., Кулаєвим Ю.Ф., Полянською Н.С., Полянською Н.О., Садловською І.П., Шаповал Н.С. [1-8]. У монографії Кулаєва Ю.Ф. автором розглянуто основні поняття економіки аеропорту та авіакомпанії [1]. Полянська Н.С. в своїй монографії розглядає регулювання міжнародного повітряного транспорту та відповідальність при перевезеннях повітряним транспортом, а також взаємодію авіакомпаній та аеропортів 3 формування комерційного завантаження повітряних суден [2]. Садловська І.П. розглядала взаємодію аеропортів i авіакомпаній та стратегії їхнього сумісного розвитку, запропонувала вимоги та основні характеристики економічного розвитку авіатранспортних підприємств 3 урахуванням особливостей функціонування авіакомпаній та аеропортів [5,6]. У статті Бугайко Д.О., Терещенко А.В. розглянуто проблему співпраці аеропортів 3 іншими суб'єктами транспортного ринку при виконанні повітряних перевезень та запропоновані шляхи підвищення ефективності взаємодії між цими суб' єктами [8]. Криворучко О.В. провела дослідження проблем перспективного розвитку та дослідження факторів функціонування хендлінгових компаній відповідно функціям і стратегічним цілям впровадження аеропортових послуг [9]. В роботі Полянської Н.О. запропоновано дослідження механізму спрямованого на інтереси визначених авіаційних суб'єктів й розвитку діяльності цивільної авіації України [10].

\section{Проблематика даного питання}

Проблема якісної взаємодії суб'єктів цивільної авіації в наш час в умовах нестабільних ринкових відносин $є$ актуальною, оскільки набувають подальшого розвитку відносини хендлінгу та авіакомпанії.

Значення цієї проблеми визначається різким падінням попиту на авіаційні перевезення, необхідністю додаткового фінансування на переобладнання аеропортів та повітряних суден авіакомпаній у відповідності 3 міжнародними вимогами, дотримання норм і правил щодо безпеки польотів і авіаційної безпеки, а також погіршення технічного стану аеропортів та повітряних суден авіакомпаній внаслідок відсутності фінансування на проведення ремонтних робіт.

Таким чином, задача забезпечення ефективної взаємодії аеропортів та авіакомпаній України $\epsilon$ нагальною проблемою в умовах, що склалися.

\section{Постановка завдання}

Метою статті $€$ дослідження взаємодії хендлінгової компанії та авіакомпаній, що дозволить здійснити діагностику діяльності авіакомпанії в даному аеропорту i, таким чином, в подальшому побудувати співпрацю аеропорту 3 даною авіакомпанією для задоволення потреб споживачів та досягнення найбільшого ефекту функціонування аеропорту.

\section{Результати та їх обгрунтування}

В Україні потенціал розвитку ринку авіаційних перевезень $є$ надзвичайно високим. Це обумовлено наявністю великої чисельності населення, його стрімкою урбанізацією, значною кількістю великих міст, а також вигідним географічним розташуванням України на перехресті транзитних шляхів між Сходом та Заходом. Використання цього потенціалу збільшуватиметься в умовах відновлення економічного зростання, а також поступового підвищення платоспроможного попиту населення, його запитів на авіаперельоти у справах бізнесу та туризму. Зазначене свідчить про необхідність розвитку діяльності хендлінгових компаній на українському ринку авіаційних послуг і наземного обслуговування авіарейсів. Хендлінгові компанії пропонують для авіакомпаній весь комплекс послуг, виступаючи при цьому як єдиний оператор всіх підприємств, що працюють в аеропорту.

Слово «хендлінг» утворене від англійського словосполучення ground handling, що означає наземне обслуговування авіарейсів. Тому компанії, що займаються всією наземною діяльністю повітряних суден, називають хендлінговими. Вони виступають в якості єдиного оператору всіх підприємств, що працюють в аеропорту.

Хендлінгова компанія, яка $\epsilon$ агентом підприємств комплексу аеропорту, діє на основі єдиного договору з авіаперевізниками на організацію наземного обслуговування в аеропорту і представляє інтереси авіакомпаній при взаємних відносинах 3 підприємствами аеропорту. У бізнес-авіації існують хендлінгові агенти-компанії, супроводжуючі i регулюючі всю процедуру обслуговування літака i пасажирів $з$ урахування особливостей літаків бізнескласу і виконуваних на них VIP-рейсів. 
Основними особливостями при обслуговуванні рейсів бізнес-авіації $є$ :

- нерегулярність бізнес-польотів i, як наслідок, оперативні зміни часу прильоту/вильоту, зміни маршруту тощо;

- необхідність внесення оперативних змін до графіку обслуговування повітряного судна;

- використання нових технологій для якісного обслуговування повітряних суден, використання нових IT-технологій;

- візова підтримка для членів екіпажів, що виконують бізнес-рейси;

- підвищені вимоги до безпеки повітряних суден і пасажирів;

- особливі вимоги до бортового харчування, що надається як пасажирам, так і членам екіпажу.

Агенти, що пропонують хендлінгові послуги, для бізнес-авіації здійснюють контроль і координацію усіх етапів обслуговування літака i пасажирів. Представник агента повністю супроводжує рейс, починаючи з отримання дозволів на переліт і посадку повітряних суден за маршрутом прямування, оперативно вирішує питання, що виникають.

Основними хендлінговими послугами є:

1. організація супроводу та організаційноправової підтримки дозволу на переліт та посадку повітряного судна;

2. управління

ресурсним потенціалом,запасами паливно-мастильних матеріалів та їх логістика;

3. продаж флайт-плану;

4. дотримання технічних i санітарних норм повітряного судна;

5. розміщення екіпажу в готелях;

6. забезпечення членів екіпажу візою;

7. обслуговування пасажирів в VIP-терминалі.

Під час обслуговування рейсів ділової авіації до обов'язків хендлінгової компанії, крім звичайних послуг, можуть включатися додаткові послуги, які $є$ основними елементами схеми взаємодії авіакомпаній та хендлінгових компаній (рис. 1):

1. допомога в оперативному отриманні дозволу на переліт та посадку повітряних суден за маршрутом слідування, термінові дозволи;

2. організація VIP послуг в аеропортах для пасажирів та членів экипажу;

3. координація дій кетерингу або самостійна доставка харчування на борт;

4. візова підтримка для членів екіпажів (оформлення віз в консульському пункті в аеропорту), якщо $€$ відповідний договір 3 міністерством внутрішніх справ;
5. бронювання готелів для членів екіпажів;

6. надання транспорту для екіпажу, а при необхідності і для пасажирів бізнес- рейсів;

7. підготовка брифінгів для екіпажу;

8. організаційна, технічна та економічна підтримка упродовж рейсу;

9. розрахунок і калькуляція зборів аеропортів тощо.

Хендлінг суттєво відрізняється від сервісних послуг, що надаються для повітряних суден регулярної авіації якістю послуг, хоча процедури обслуговування регулярних рейсів і VIP-чартерів здійснюються за єдиними правилами цивільної авіації.

Розглядаючи використання українськими аеропортами хендлінгових компаній потрібно сказати, що 93-95\% ринку пасажирського обслуговування та $65-70 \%$ наземного обслуговування літаків в аеропорту "Бориспіль" належить "Інтеравіа" та "Аерохендлінгу". Натомість решта часток належать службам аеропорту.

Власником 99,9\% компанії «Аерохендлінг» $\epsilon$ кіпрська компанія Renorm Limited, яка у свою чергу належить іншій кіпрській компанії - S.I. Cylaw Services Limited. Остання відома в Україні як секретарська компанія, що володіє активами в інтересах інших клієнтів. Серед нинішніх клієнтів кіпрської S.I. Cylaw Services Limited $є$ і засновник MAУ - кіпрська компанія Ontobet Promotions Limited.

Міжнародний аеропорт «Бориспіль» дозволив ще одній хендлінговій компанії, що надає послуги 3 пасажирського і наземного обслуговування «Аеропорт Хендлінг» займатися обслуговуванням своїх пасажирів.

Підприємство «Аеропорт Хендлінг» засноване у вересні 2010 року. Статутний фонд становить 10 тисяч гривень. Засновником «Аеропорт Хендлінг" виступає зареєстрована в Лондоні компанія Airport Development Solutions Ltd.

Аеропорт «Київ» (Жуляни) проводить повне наземне обслуговування рейсів компанії Мастер-Авіа. Компанія Мастер-Авіа заслужила свою репутацію завдяки системі кваліфікованих сертифікованих фахівців; більш ніж 50 одиниць сучасного обладнання i техніки від кращих міжнародних виробників; відповідності і дотримання всіх міжнародних вимог i процедур; наявності необхідних дозвільних документів та сертифікатів від державних i міжнародних інстанцій на всі види діяльності; використання автоматизованої системи SITA .

Компанія оснащена всім необхідним та надає послуги на найвищому рівні. Зокрема, компанія пропонує наступні послуги: 


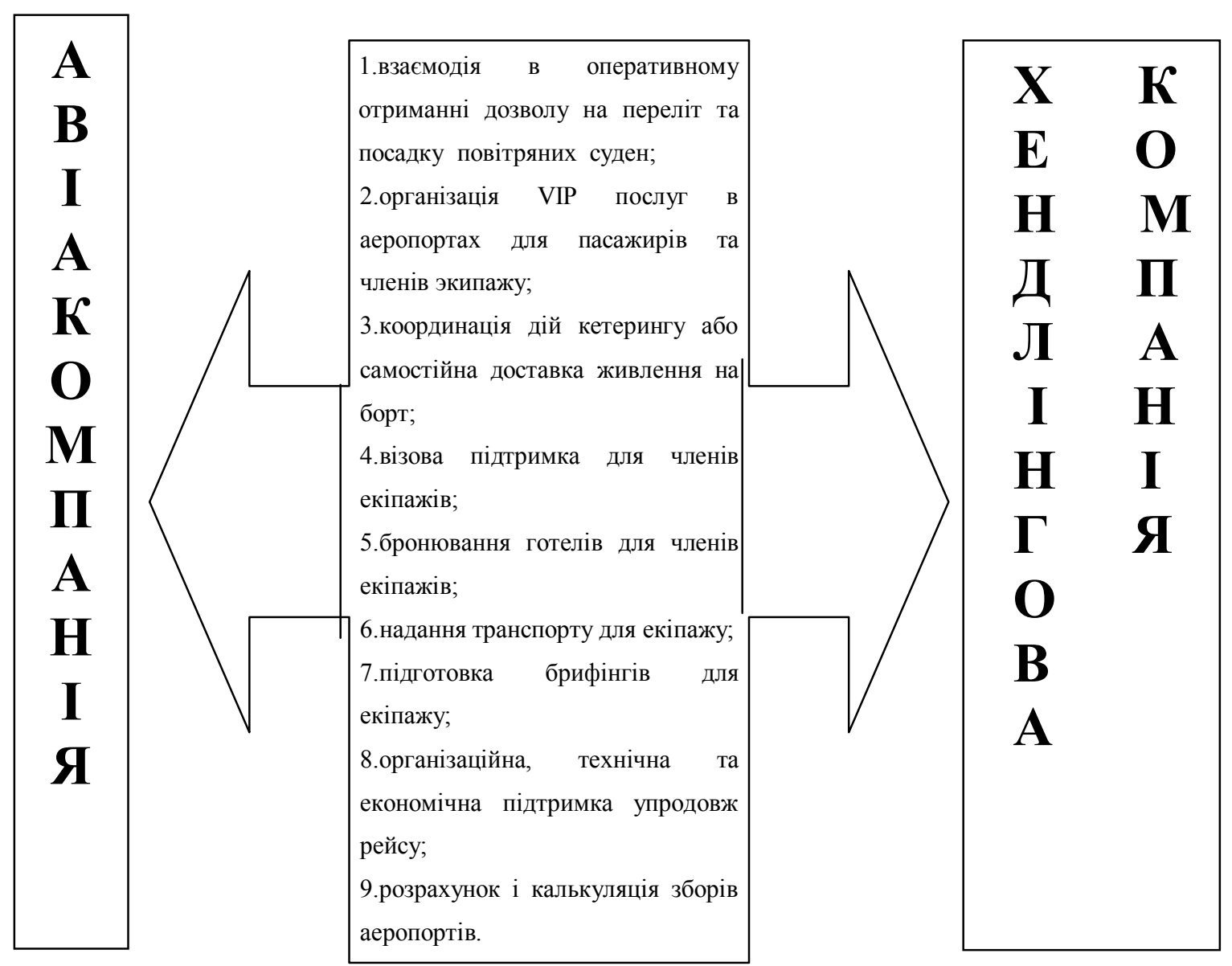

Рис.1 Схема послуг хендлінгової компанї з авіакомпанією ї

- протильодову обробку повітряних суден. Компанія володіємо різними типами протильодових рідин для максимально ефективного захисту повітряного судна та забезпечення безпеки польотів в будь-яких погодних умовах;

- підготовку та обслуговування рейсів на виліт у відповідності 3 усіма вимогами авіакомпаній за допомогою сучасної глобальної автоматизованої системи SITA, яка забезпечує, підтримує сучасні методи відпрацювання електронних квитків всіх систем бронювання, що працюють у форматі IATA, дозволяє виробляти онлайн реєстрацію, реєстрацію трансферних пасажирів i їx багажу до кінцевого пункту прямування;

- розрахунок центрування повітряного судна. Дана послуга включає: ведення бази даних по повітряним судам, що експлуатуються, розрахунок центрування повітряного судна в автоматизованому режимі.

Взаємодія хендлінгової компанії 3 кожною авіакомпанією відбувається 3 урахуванням наступних показників, які в комплексі можуть адекватно оцінити діяльність кожної авіакомпанії $з$ даною хендлінговою компанією: кількість перевезених пасажирів та обсяги перевезених вантажів за всіма рейсами аеропорту, розклад авіакомпанії, розрахунок 3 хендлінговою компанією за встановленими тарифам, додаткове обслуговування у встановлених межах без затримки.(Рис.2)

Суттєвим факторами взаємодії авіакомпанії та хендлінговою компанією $є$ вчасність розрахунків та кількість пасажирів, яких обслужили за минулий місяць.

Ці фактори визначають рівень знижок, які авіакомпанія отримує 3 хендлінгової компанії. Якщо авіакомпанія отримує знижки, то вона набуває статусу постійного клієнту хендлінгової компанії.

\section{Висновки}

Хендлінгові компанії $є$ активними учасниками процесу надання авіаційних послуг. До їх завдань входить не лише покращення обслуговування існуючих клієнтів з метою задоволення зростаючих потреб, але і залучення нових авіаперевізників. Процеси взаємодії хендлінгових структур аеропорту 3 авіакомпаніями відносяться до стратегічних процесів аеропорту. Створена схема взаємодії хендлінгової компанії 3 авіакомпанією виявляє проблемні авіакомпанії і $є$ однією із складових для розробки стратегії розвитку аеропорту. 


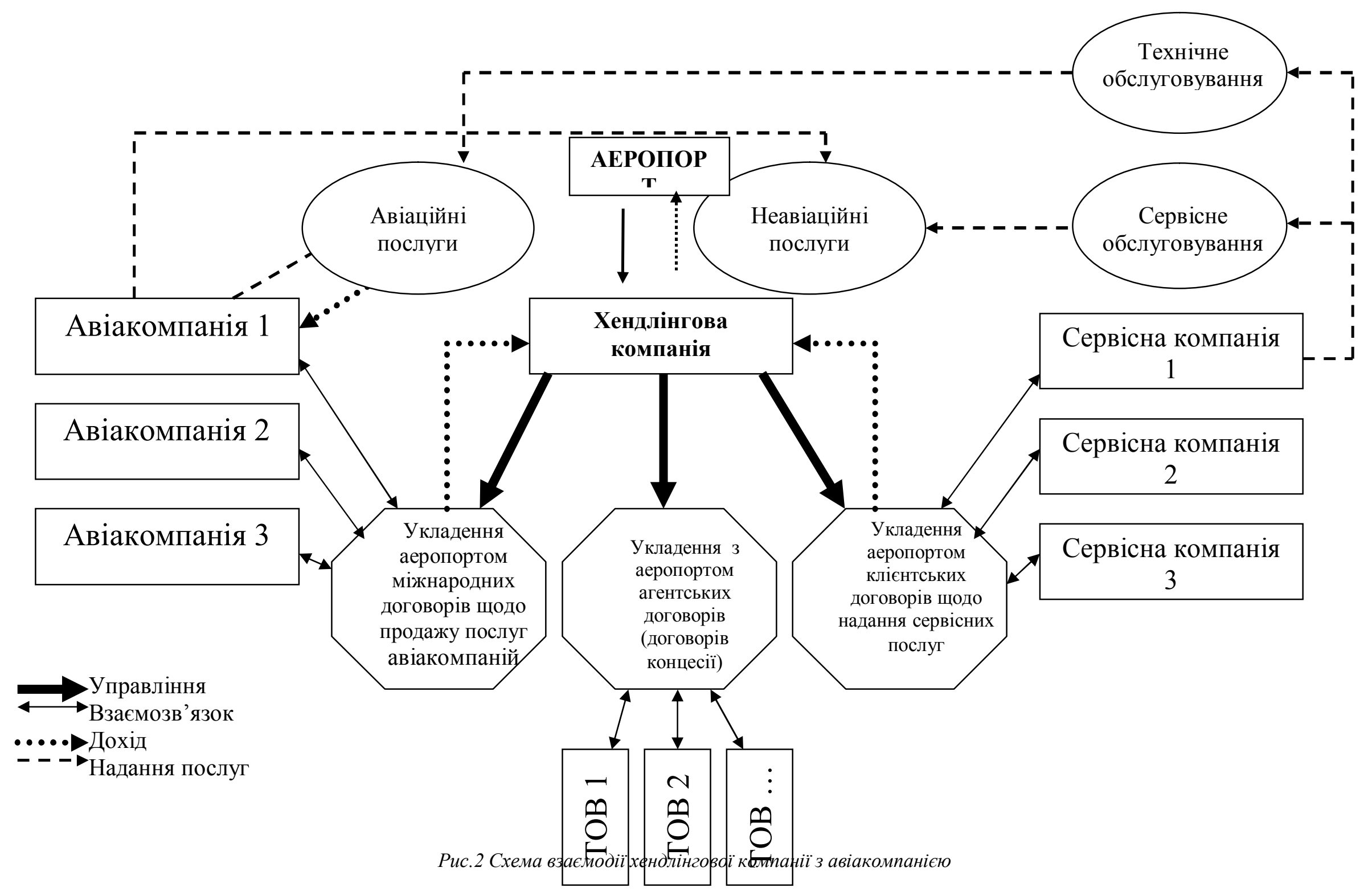

Вісник економіки транспорту і промисловості № 49, 2015 


\section{СПИСОК ЛІТЕРАТУРИ}

1. Кулаев Ю. Ф. Экономика гражданской авиации Украины. Монография.- К.: Издательство «Феникс», 2004. - 667 с.

2. Полянская Н. Е. Организация коммерческой работы на воздушном транспорте. K.: НAУ,2004. - 320c.

3. Полянская Н.Е., Шаповал Н.С. Умови підвищення економічного потенціалу аеропорту // ABIA - 2003: Матеріали V Міжнародної науково технічної конференції. - т. V - VI.- К.: НАУ, 2003. -Секція «Економіка та підприємництво». - С.6.86 6.89.

4. Ложачевська О.М., Шаповал Н.С. Факторы, влияющие на развитие воздушного транспорта Украины // Економіст. - 2002. - №7. - С. $96-97$.

5. Садловська I. Методичні рекомендації 3 формування стратегії розвитку авіатранспортних підприємств// Відомості міністерства транспорту та зв'язку України. - 2005. - №6. - С.12 - 14.

6. Садловська І.П. Формування стратегії економічного розвитку авіатранспортних підприємств: Автореферат дис. канд екон.наук: 08.07.04. - К.: HAУ, 2004. - 19 c.
7. Костромина Е.В. Экономика авиакомпании в условиях рынка. - М.: НОУ ВКШ «Авиабизнес», 2002. $-304 \mathrm{c}$.

8. Бугайко Д.О., Терещенко А.В. Взаємодія суб'єктів транспортного ринку в міжнародних аеропортах // Наукоємні технології. - 2009. - № 2. C. $1-5$.

9. Криворучко О.В. Перспективи розвитку хендлінгових компаній на українському ринку авіаційних послуг // Проблеми системного підходу в економіці, 2009, №30. - С. 159-163.

10. Полянська Н.О. Управління державноприватним партнерством на ринку авіаційних перевезень. Автореферат дис. канд екон.наук: 08.00.04. - K.: HAУ, 2009. -20 c.

11. Наземне обслуговування [Електронний ресурс]: - Електрон. дан. (1 файл). - К., 2014. 18 c. - Режим доступу : http: //www.airport.kiev.ua/ /partners/ground_handling - Назва з екрана.

12. Кучеренко А.І. Розвиток хендлінгових компаній на українському ринку авіаційних послуг [Електронний ресурс] :- Електрон. дан. (1 файл). - К., 2012. - Режим доступу : http:// er.nau.edu.ua/bitstream/NAU/12422- Назва з екрана.

Рецензент д.е.н., професор ІЕМ Смерічевський С.Ф. Експерт редакційної колегії к.е.н., дочент УкрДУЗТ Уткіна Ю.М.

УДК 330.341.1:656.2

МЕТОДИКА ОЦІНКИ КАДРОВОГО ПОТЕНЦІАЛУ СЛУЖБИ ЗАЛІЗНИЦІ

\author{
Назаренко І.Л., к.е.н., доцент, \\ Маслова В.О., к.е.н., доцент, \\ Погрібна Я.Д., магістр (УкрДУЗТ)
}

\begin{abstract}
В статті удосконалено методику оиінки кадрового потенціалу для служби залізниці шляхом визначення питомих вагів значущості часткових показників за допомогою експертних оцінок (метод Дельфі). Найбільш важливими для оцінки кадрового потенціалу служби залізниці виявилися показники освіти, творчої активності персоналу, навчання персоналу, підвищення кваліфікації та плинності кадрів. Виконано розрахунки за матеріалами служби матеріально-технічного постачання Донецької залізнииі у 2010 - 2014 рр.

Ключові слова: кадровий потенціал, залізничний транспорт, служба залізниці, методика оцінки кадрового потенціалу.
\end{abstract}

\title{
МЕТОДИКА ОЦЕНКИ КАДРОВОГО ПОТЕНЦИАЛА СЛУЖБЫ ЖЕЛЕЗНОЙ ДОРОГИ
}

\author{
Назаренко І.Л., к.э.н., доцент, \\ Маслова В.О., к.э.н., доцент, \\ Погребная Я.Д., магистр (УкрГУЖТ)
}

В статье усовершенствована методика оценки кадрового потенциала для службы железной дороги путем определения удельных весов значимости частных показателей с помощью экспертных оценок (метод Дельфи). Наиболее важными для оиенки кадрового потенциала службы железной дороги оказались

(C) Назаренко І.Л.,

Маслова В.О.,

Погребная Я.Д.
Вісник економіки транспорту і промисловості № 49, 2015 